\title{
RELATIONSHIPS OF PROTEIN INTAKE AND WEIGHT TRAINING WITH MUSCLE MASS AMONG FITNESS CENTER MEMBERS
}

\author{
Ryan Rohmansyah'), Muchsin Doewes²), Agus Kristiyanto²) \\ 1)Masters Program in Nutrition, Universitas Sebelas Maret \\ 2)Masters Program in Sport Sciences, Universitas Sebelas Maret
}

\begin{abstract}
Background: The current era of modernization requires someone to look athletic, one of them is by making muscle mass formation, especially in men. Many things are done to fulfill these desires, including weight training. Weight training is a common type of strength training for developing the strength and size of skeletal muscles. Protein intake is also important for the development of skeletal muscles. This study aimed to examine the relationship of protein intake and intensity of weight training with muscle mass among fitness center members.
\end{abstract}

Subjects and Method: This was a cross sectional study conducted at Victory fitness center, Yogyakarta. A sample of 31 fitness members was selected for this study. The dependent variable was muscle mass. The independent variables were percent of protein intake and intensity of weight training. Muscle mass was measured by midline and skinfold. Percent of protein intake was measured by 24 hour-food recall and the data were analyzed by Nutrition Survey 2008. Intensity of weight training was measured by observation. The data were analyzed by a multiple linear regression.

Results: Protein intake was low in 19 (61.29\%) subjects. Intensity of weight training was low in 15 (48.3\%) subjects. Muscle mass was small in 17 (54.8\%) subjects. Muscle mass increased with high percent of protein intake $(b=0.35 ; p=$ 0.044) and high intensity of weight training $(b=0.98 ; p=0.037)$.

Conclusion: Muscle mass increases with weight training and protein intake among fitness center members.

Keywords: muscle mass, protein intake, weight training, fitness member

\section{Correspondence:}

Ryan Rohmansya. Masters Program in Nutrition, Universitas Sebelas Maret, Jl. Ir. Sutami 36A, Surakarta 57126, Central Java.

Email: ryanrohmansyah22@gmail.com Mobile: 082338555515 